\section{References}

Akiner, Shirin. 1983. Islamic People of the Soviet Union. London: Kegan Paul International.

Avtorkhanov, Abdurahman. 1992. "The Chechens and the Ingush during the Soviet Period and its Antecedents." In The North Caucasus Barrier: The Russian Advance towards the Muslim World, edited by Marie Broxup Bennigsen, 146-94. New York: St. Martin's Press.

Bennigsen Broxup, Marie. 1992a. "Introduction: Russia and the North Caucasus." In The North Caucasus Barrier: The Russian Advance towards the Muslim World, edited by Marie Bennigsen Broxup, 1-17. New York: St. Martin's Press.

Bennigsen Broxup, Marie. 1992b. "After the Putsch, 1991." In The North Caucasus Barrier: The Russian Advance towards the Muslim World, edited by Marie Bennigsen Broxup, 219-40. New York: St. Martin's Press.

Furnival, J. S. 1967. Netherlands India: A Study of Plural Economy. Amsterdam: B.M. Israel.

Gallagher, James P. 1995. "Crazy with fear, Russian army lashes out at civilians." America Online, Inc., transmitted by electronic mail by root@newsbf02.news .aol.com on February 12.

Gary, John. 1993. "Yeltsin Closes Papers, TV Show. Moscow Police Crack Down on Suspected Criminals." The Globe and Mail, October 15

Caplin, Fred. 1993. "Moscow Cracks Down on Outsiders, Police Take Advantage of State of Emergency to Drive Many Ethnics from City." The Boston Globe, October 14.

McGarry, John, and Brendan O'Leary, eds.. 1993. The Politics of Ethnic Conflict Regulation. London: Routledge.

Ryan, Stephen. 1990. Ethnic Conflict and International Regulation. Dartmouth: Aldershot.

Simon, Gerhard. 1991. Nationalism and Policy Toward the Nationalities in the Soviet Union: From Totalitarian Dictatorship to Post-Stalinist Society, translated by Karen Forster and Oswald Forster. Boulder: Westview Press.

Smith, M. G. 1971. "Some Developments in the Analytic Study of Pluralism." In Pluralism in Africa, edited by Leo Kuper and M.G. Smith. Berkeley: University of California Press.

York, Geoffrey. 1995a. "Yeltsin pledges reform of military." The Globe and Mail, February $17, \mathrm{A1}, \mathrm{A12}$

York, Geoffrey. 1995b. "Cities of Russia cruel to southerners." The Globe and Mail, January $30, \mathrm{~A} 1, \mathrm{~A} 10$..

\title{
Chechnya's Refugees Within North Caucasus: Reality and Problems
}

\author{
Eugene V. Kritski
}

In the last few years, the North Caucasus has become an area in which significant migratory activity has taken place. Its numerous regions, which vary with respect to demographic, economic and political characteristics, have been either sources or destinations of migratory flows, or in some cases, both. Since 1990, migration has played an important role in the region, sometimes merely reflecting certain ethnopolitical conflicts within the region and sometimes contributing to them. In fact, migration provides a link between those regions where ethnic conflicts have fully developed and those where such conflicts are still dormant but have a potential for flaring. Steady outmigration has occurred in those regions which have experienced tense interethnic relations and ethnic violence, such as Abkhasia, Ingushetia, North Ossetia and Chechnya. The migratory flow caused by the recent war in the Chechen Republic is now considered to be of most influence upon social and political stability within the region and its parts.

Two approaches can be used to describe the current phenomenon of mass-scale refugee flow from Chechnya. The first is a macroapproach, based on a statistical description of the number of migrants, directions of their flows, and on an analysis of humanitarian activity by governmental and nongovernmental organizations. The second involves a micro-level reconstruction of socialpsychological aspects of migration, including subjective factors (exterior and interior) of social adaptation of

Dr. Eugene V. Kritski is the director of North Caucasian Centre of the Institute for Social and Political Research of the Russian Academy of Sciences, Moscow. refugees, their expectations, orientations, and the extant psychological climate. Since the author has not had an opportunity to pursue a micro-level field research among Chechen $\mathrm{mi}$ grants, this article will be based on the first approach.

Certain difficulties were encountered in gathering and interpreting the collected data. To begin with, there is much confusion over the terms used in different sources of information to refer to people who were forced to leave their homes. Most call these persons "refugees" although from the point of view of international law, they should be called "forced migrants." The Federal Migratory Service (FMS) uses the designation of "forced migrants," although in its public statements and interviews its employees use the term "refugee" as a synonym of "forced migrant." Yet the two are not the same. If refugees agrees to settle in areas designated for them, such as mid-Russia, Siberia and the Urals, they receive the legal status automatically. But to obtain a status of a "forced migrant" in areas not designated for refugee settlement one needs to obtain domicile registration ("propiska"). Yet, the only legal grounds for getting "propiska" are having close relatives or owning a house or a flat. Since most refugees do not meet these requirements, they were not able to obtain a legal status. Consequently, official figures of "forced migrants" are considerably lower than those with which non-official institutions operate. Thus there is a gap between the numbers of refugees who exist de facto and de jure. We should also note that a data base on forced migration from the Chechen Republic is still incomplete. This creates special obstacles, such as difficulties in getting and verifying information. In this case, a researcher 
risks basing an analysis upon false figures and pretentious opinions. Chronological coincidence of the phenomenon in question and its analysis produces the so-called "aberration of closeness." Moreover, the data under consideration are often inconsistent and rely on different categories, depending on the source.

This article is based on the information taken from documents published by governmental and non-governmental organizations and by mass media. We also interviewed FMS officials. These interviews were conducted by telephone.

Since the beginning of the crisis, approximately 140,000 of Chechnya's inhabitants were forced to leave their homes for North Caucasian districts and republics, and about 70,000 for other regions of Russia. These refugees could be placed in one of three categories. Those in the first and smallest category, consisting of some 40,000 people, have been displaced internally within the territory of Chechnya. The majority of refugees can be found in the second category of those who found shelter in Daghestan and Ingushetia. The third category, is composed of those who have moved to the Krasnodar and Stavropol districts.

Migration from the Chechnya region had preceded the current crisis. According to an estimate by FMS's Director, at least 400,000 people have migrated from Chechnya since 1991, with only half of them having received the official status of a 'forced migrant.' FMS, placed in charged of forced migrants, has created a system of regional operative groups which are to be coordinated centrally. These groups are responsible for the registration and voluntary repatriation of refugees to those areas in which the political situation has normalized. FMS allocated 17 billion roubles to regional branches to cover food, clothing and transportation costs of refugees. Additionally, about 3.5 trillion roubles were dispatched for house-building.

In 1994, the Stavropol district (krai) received 7,703 persons from Chechnya -58 percent of all forced migrants reg- istered by the local branch of FMS. Since the beginning of the war until February 1, 1995, 3,000 more persons have been registered. According to FMS officials, only one-fourth of the refugees applied for official status. Many chose not to register because there is no advantage in doing so. The one-time emergency aid they receive is extremely low, equal to a minimum monthly earning $(25,000$ roubles or $\$ 6)$. Almost all applicants were granted the status.

In 1994, the Krasnodar district (krai) branch of FMS registered 929 people from Chechnya as "forced migrants," constituting $98 \%$ of all those who applied for the status. There was a significant upsurge of migratory activity in January 1995 (see Table 1).

\begin{tabular}{|lc|}
\hline \multicolumn{2}{|c|}{ Table 1: } \\
$\begin{array}{c}\text { Number of Forced Migrants } \\
\text { Registered in the } \\
\text { Krasnodar District }\end{array}$ \\
\hline Period & \# of Registrants \\
1994 January & 149 \\
February & 181 \\
March & 108 \\
April & - \\
May & 73 \\
June & 50 \\
July & 85 \\
August & 98 \\
September & 47 \\
October & 24 \\
November & 50 \\
December & 64 \\
January & 2,280 \\
\hline
\end{tabular}

According to FMS officials, the real number of refugees who arrived in January of 1995 is five times higher. Percentage ethnic composition of the refugees are as follows: Russians 94; Armenian 2; Chechens 1; Ingushtians 2; Other 1. The ethnic composition of the region is therefore not affected and does not pose a threat to interethnic relations there.

As mentioned above, most forced migrants escaped to neighbouring republics of Ingushetia and Daghestan. To understand the situation in which migrants find themselves in Ingush- etia, we should take into account the specificity of the Ingushtians' ethnic and political history.

Ingushetia is the most recently established republic in North Caucasus. Its territory covers about 2,000 square $\mathrm{km}$., with the population of about 215,000 people. Ethnic Ingushtians constitute the majority of the population in this republic.

Since the eruption of a violent conflict between Ingushtians and Ossetians over the Prigorodny district of Vladikavkaz, Ingushetia received 60,000 migrants, 50,000 of whom are still living in the republic. Both Ingushtians and Chechens belong to the "vainach" ethnolinguistic community and their languages are mutually comprehensible. Both Chechens and Inguishes identify themselves as "vainach-speakers." They are also linked by ties of kinship. In both Chechnya and Ingushetia the clan (taip) system is still alive. And it is important to point out that some clans consist of both Ingush and Chechen families. Furthermore, the border between Chechnya and Ingushetia is still not fully drawn. In 1934, the Chechen and the Ingush autonomous districts were amalgamated, and in 1936, the new district's status was changed to the Chechen-Ingush Autonomous Republic. In February 1944, thousands of Chechens and Ingushes were deported to Central Asia and Siberia, but after the official rehabilitation in 1957, the Republic of Checheno-Ingushetia was re-established. It was only in 1992 that Chechnya separated from the Republic and declared its independence. Following the declaration, the Ingush Republic was established.

Since the eruption of the war, the migratory flow has been increasing from 500 to 2,000 per day. By January 24, 1995, 55,509 Chechens had been registered as forced migrants. Most of them are in Nazran. Fifteen train cars have been used as shelter for refugees but these have proven insufficient. Many refugees have found shelter among their relatives. Some families host up to fifty migrants. In an interview, given to Severny Kavkaz on 
January 28, 1995, the Head of the Migratory Service of the Republic of Ingushetia complained that the republic can no longer stretch its hospitality and that the agency is considering stopping the registration of refugees. Yet, resettlement of these refugees (who are predominantly Ingushes and Chechens) to mid-Russia, Siberia and Ural are not viable options either, since in the minds of the refugees they would be associated with the forced deportations they suffered under Stalin. Only 2,838 refugees have accepted resettlement to these regions.

The migratory situation is also complicated by the presence of the socalled "shuttle" refugees in Ingushetia. These are Dudaev's combat men. Some of them have been detained by the federal forces and have been charged by the Ingush Republic's Prosecutor's office. Approximately 5,000 forced migrants were registered in North Ossetia by February 1 . Since the Republic has already accepted a great number of refugees from Central Asia and Georgia, it has imposed restrictions on Chechen refugees, allowing only those with close relatives in North Ossetia to stay there. The rest are allowed to sleep in train cars at the Vladikavkaz railway station. They have been offered permanent settlement in such cities as Smolensk, Saratov, Tambov, and Novgorod. Refugees receive assistance for three months and then they have to make a decision either to resettle or to stay in the area unassisted.

Daghestan has received approximately the same number of forced migrants as Ingushetia. Strict quantitative characteristics of the migratory flows from Chechnya are difficult to calculate. Figures partly depend on methods of registration of refugees by different institutions. There are three sources of data in Daghestan: the Daghestanian branch of FMS, offices of ethnopolitical communities that register migrants of their ethnic background, and the Territorial Medical Association of the district of Khasavjurt (See Table 2 below for the first two sources).

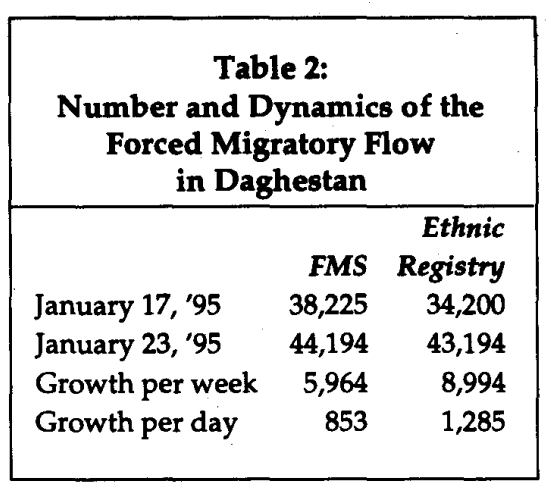

Figures given by the offices of ethnopolitical communities seem to reflect the migratory situation more adequately, because they count all persons who have arrived in Daghestan, whether officially registered or not. The Territorial Medical Association of the district of Khasavjurt reported an even higher number of refugees. At least 51,200 had arrived by January 20 . The numbers offered by the Ministry of Labour are lower for a number of reasons. First, some refugees chose not to register as forced migrants since the assistance they expected to receive from FMS was so insignificant. Second, it is possible that others did not register because they would not meet the eligibility requirements.

Finally, it is possible that some of these refugees were the so-called 'shuttle' migrants, or Dudaev's combat men who came to Daghestan to procure medical assistance and temporary shelter. The Medical Association reported about 373 refugees being wounded (January 29), and $80 \%$ of them were men. As military activities intensify in the Western part of the Chechen republic, the number of this type of migrants may increase. Refugees residing in Daghestan have the potential for contributing to the regions' own ethnopolitical and demographic problems. It is important to consider the ethnic composition of the refugee flow and that of the districts in which these refugees settle. Ethnic composition of forced migrants in Daghestan are Chechens 64\%; Peoples of Daghestan 22\%; Russians 13\%; Other $1 \%$.
Since the predominant majority of the refugees are non-Russians, they are more likely to chose to stay in the area, with only very few opting to resettle in the regions of Russia mentioned above. By January 17, only 500 refugees have chosen to resettle there. Most of the reception centres are located in the regions contiguous with the Chechen Republic. In order to prevent the spread of the conflict, the Daghestan authorities have prohibited the organization of such centres inside Daghestan. Most refugees have settled in the district of Khasavjurt. The district has been inhabited by Kumyks, Chechens (approximately 60,000 Chechen live there under the name of Akki), and Avars. For the last four years this area of Daghestan has witnessed increasing inter- ethnic competition. Ethnic organizations have emerged to promote and defend the rights of their respective communities. The objective of the Kumyk movement, "Tenglik," is to create a democratic Autonomous Kumyk Republic. Chechens-Akki in their turn have put forward a demand to transfer this territory (which in fact was part of Chechnya prior to the deportation of Chechens in 1944) to the Chechen Republic. The growth of the Chechen population in this district as a consequence of forced migration may provoke the escalation of ethnic violence. And some have already called for the extension of military action into Daghestan at political rallies held in Khasavjurt.

\section{The Genesis of $A$} Domestic Regime: The Case of Hungary

Edited by Howard Adelman, Endre Sik and Geza Tessenyi

ISBN 1-55014-237-2

Report, 108 pp, indexed. $\$ 14.95$

Published by

York Lanes Press 